\title{
Dependence of 3 Nebraska Sandhills warm- season grasses on vesicular-arbuscular mycorrhizae
}

\author{
J.J. BREJDA, D.H. YOCOM, L.E. MOSER, AND S.S. WALLER
}

Authors are research specialist. School of Natural Resources, University of Missouri, Columbia 65211; assistant professor, Department of Biology, Millersville University, Millersville, Penn. 17551; professors of agronomy, Department of Agronomy, University of Nebraska, Lincoln 68583-0915.

\begin{abstract}
Vesicular-arbuscular mycorrhizae (VAM) are rare or absent in actively eroding soils of the Sandhills. The objective of this study was to determine if 3 major Sandhills warm-season grasses used in reseeding eroded Sandhills sites are highly mycorrhizal dependent, and evaluate the response of VAM at different phosphorus (P) levels. In 2 greenhouse experiments, sand bluestem [Andropogon gerardii var. paucipilus (Nash) Fern.], switchgrass (Panicum virgatum L.), and prairie sandreed [Calamovilfa longifolia (Hook) Scribn.] were grown in steam-sterilized sand in pots and inoculated with either indigenous Sandhills VAM, Glomus deserticola, or noninoculated. In the second experiment, VAM inoculated and control plants were treated with 5 P levels ranging from 5.4 to 27.0 mg $P$ pot $^{-1}$. Increasing levels of $P$ fertilizer caused an initial increase, then dramatic decrease, in percentage colonization by Glomus deserticola but had no effect on percentage colonization by indigenous Sandhills VAM. Mycorrhizal inoculated plants had a greater number of tillers, greater shoot weight, root weight, tissue $P$ concentration and percentage $P$ recovered, and a lower root/shoot ratio and $P$ efficiency than noninoculated plants. Noninoculated sand bluestem had significantly lower shoot $\mathbf{P}$ concentration but greater $P$ efficiency over all $P$ levels than any other grass-VAM treatment combination. Phosphorus fertilizer and VAM effects were often complementary at $P$ levels up to 16.2 to $21.6 \mathrm{mg} \mathrm{pot}^{-1}$, with no change or a decrease in plant responses at higher P levels. These 3 major Sandhills warm-season grasses were highly mycorrhizal dependent. Successful reestablishment of these on eroded sites in the Sandhills may be greatly improved if soil reinoculation with VAM occurred prior to revegetation.
\end{abstract}

Key Words: phosphorus recovery, phosphorus-use efficiency, revegetation, grass seedlings, tillering

The Nebraska Sandhills comprise the largest continuous expanse of Tallgrass Prairie in the Great Plains, covering about $52,000 \mathrm{~km}^{2}$ in northcentral and western Nebraska (Seevers et al. 1975). Upland soils of the Sandhills are composed primarily of fine sand of high erosion potential and low organic matter content, water-holding capacity, and available nutrients. Available $\mathbf{P}$ may be the soil nutrient that has the greatest influence on the vegetative composition of range sites in the Sandhills (Burzlaff 1962).

Many areas of the Sandhills have experienced excessive erosion as a result of overgrazing and the abandonment of farming operations on center pivot irrigation sites (Kocher and Stubbendieck 1986). Vesicular-arbuscular mycorrhizae (VAM) are abundant in

\footnotetext{
Published as journal article 9932, Agr. Res. Div., University of Nebraska.

The authors wish to thank Theresa Flessner and Ilene Cunningham for greenhouse and laboratory assistance.

Manuscript accepted 3 July 1992
}

undisturbed Sandhills soils, but rare or absent in actively eroding soils (Roder 1985, Reece et al. 1987). Reseeding these sites with native and introduced warm- and cool-season grasses has often been unsuccessful (King et al. 1989). Lack of success in seedling establishment in eroding Sandhills soils may be a result of very low levels of VAM fungi present in the soils at the time of seeding (Reece et al. 1987, Reeves et al. 1979).

Vesicular-arbuscular mycorrhizae readily colonize the roots of prairie grasses (Hetrick et al. 1988). Warm-season grasses display a high degree of dependence on mycorrhizae and are often unable to survive without them (Hetrick et al. 1988, 1989; Trappe 1981, Bethlenfalvay et al. 1984). Hetrick et al. (1989) reported that inoculation of sterilized prairie soils with mycorrhizae resulted in a 7 to 70 fold increase in big bluestem (Andropogon gerardii Vitman) seedling biomass. Plant response to mineral nutrients is often highly dependent on VAM. Hetrick et al. (1989) concluded that when mycorrhizae are present, $\mathbf{N}$ is the most limiting nutrient in most rangeland soils. However, in the absence of mycorrhizae, $P$ is most limiting and no response to $\mathbf{N}$ is observed unless sufficient $\mathbf{P}$ is also applied.

Understanding the symbiotic relationship between VAM fungi and the native warm-season grasses of the Sandhills is essential for effective seeding of disturbed Sandhills soils. The purpose of this research was to examine relationships between VAM fungi and 3 native Sandhills warm-season grasses by (1) comparing the growth, P-uptake and P-use efficiency of these grasses with indigenous and introduced VAM fungi, and (2) evaluating the response at different $P$ levels.

\section{Materials and Methods}

\section{Inoculum Source and Treatments}

Two greenhouse studies were conducted utilizing indigenous Sandhills VAM fungi from the Nebraska Sandhills, and the introduced VAM fungus Glomus deserticola. Glomus deserticola was chosen for comparison with indigenous Sandhills VAM because it is not native to the Sandhills but is found in more arid environments in the western U.S. Inoculum for the Sandhills VAM treatment was prepared by collecting large blocks of sod containing root material of native Sandhills grasses from the top $30 \mathrm{~cm}$ of a Valentine fine sand (fine sandy mixed mesic Typic Ustipsamment) at a rolling sands range site at the University of Nebraska's Gudmundsen Sandhills Laboratory, located in Grant County, $12 \mathrm{~km}$ northeast of Whitman, Neb. Soil at the collection site is low in mineral nutrients, especially in available $P$. Soil properties for the top $30 \mathrm{~cm}$ were: $0.81 \% \mathrm{OM}, 0.04 \%$ total $\mathrm{N}$ (Kjeldahl), $5.7 \mathrm{mg} \mathrm{kg}^{-1}$ available $P$ (Bray and Kurtz \#1), and a pH (1:1 soil-water ratio) of 6.45. Major components of the plant community at the collection site included sand bluestem [Andropogon gerardii var. paucipilus 
(Nash) Fern.], prairie sandreed [Calamovilfa longifolia (Hook) Scribn.], switchgrass (Panicum virgatum L.), little bluestem [Schizachyrium scoparium (Michx.) Nash.], and needleandthread (Stipa comata Trin. and Rupr.). Mycorrhizae native to the collection site and present in the Sandhills VAM inoculum included Glomus fasciculatum, G. mosseae, G. macrocarpum, Sclerocystis dugesia, and Gigaspora spp. Inoculum for the $G$. deserticola treatment was collected from sorghum (Sorghum bicolor $\mathrm{L}$.) pot cultures previously inoculated with the fungus and maintained in a $20-27^{\circ} \mathrm{C}$ greenhouse.

Inoculum for both VAM treatments was prepared by removing the plant tops and thoroughly washing the roots to remove all soil and adhering spores, and refrigerating at $4^{\circ} \mathrm{C}$ prior to use. Half the root mass from both inoculum sources was combined and autoclaved at $100^{\circ} \mathrm{C}$ for 1 -hour to sterilize to serve as a control treatment. Roots were cut into $2-\mathrm{cm}$ pieces and $14 \mathrm{~g}$ (fresh weight) of root material was added to each pot in a layer $2.5 \mathrm{~cm}$ below the soil surface. Filtered washings ( $20 \mu \mathrm{m}$ sieve) from a mixed sample of all inocula was added to each pot to insure all pots developed a similar microflora except for mycorrhizal fungi (Linderman and Hendrix 1982). Coarse sand steamed for 1 hour to sterilize was used as the soil medium. Pots had a total volume of $1.9 \mathrm{~L}$, and a depth of $25 \mathrm{~cm}$.

Seeds of sand bluestem, prairie sandreed and switchgrass were surface sterilized by soaking in a $10 \%$ solution of commercial chlorine bleach for 3 minutes. Seeds were sown in each pot in excess of final density and covered with $1 \mathrm{~cm}$ of sterile sand. Immediately after seeding, each pot was watered thoroughly and allowed to drain freely. Seedlings emerged within 3 to 6 days and were thinned to 3 plants per pot after 1 week. Long Ashton nutrient solution (Hewitt 1966) containing all essential nutrients except $P$ was added to all pots weekly to insure that only $P$ was on limited supply. Phosphorus level for the first study totaled $5.4 \mathrm{mg} \mathrm{pot}^{-1}$ distributed over 12 applications at weekly intervals in $100-\mathrm{ml}$ aliquots. Five $P$ levels of 5.4, 10.8, 16.2, 21.6, and $27 \mathrm{mg} \mathrm{pot}^{-1}$ were used for the second study and were applied in the same manner as in the first study. The lowest $P$ level used in this study $\left(5.4 \mathrm{mg} \mathrm{pot}^{-1}\right)$ was chosen because it represented an average $P$ concentration found in the top $30 \mathrm{~cm}$ of Nebraska Sandhills rolling sands soils. Plants were watered as needed at 2- to 3-day intervals and allowed to drain freely. The photoperiod was extended to 16 hours with metal halide lamps that produced $55 \mathrm{~W} \mathrm{~m}^{-2}$ and the greenhouse temperature was maintained between 20 and $27^{\circ} \mathrm{C}$. Both experiments were 13 weeks long. The first greenhouse experiment was planted 8 October, and harvested on 6 January. The second greenhouse experiment was planted on 25 April and harvested on 24 July.

\section{Data Collection and Analysis}

At each harvest the number of tillers per pot was determined and shoots were separated from roots with the crown assigned to the shoots. Roots were washed free of soil and the shoots and half the root mass were dried separately at $70^{\circ} \mathrm{C}$ for 48 hours in a forced air oven and weighed. Shoots were ground in a Wiley mill to pass a 1-mm screen, dry ashed, and analyzed for total $P$ content by the University of Nebraska-Lincoln Testing Laboratory. Phosphorus efficiency was calculated as g of shoot dry matter produced per $\mathrm{mg}$ $P$ accumulated in the shoot dry weight (Elliott and Lauchli 1985, Marschner 1986).

A subsample of the fresh root mass was cleared in $10 \% \mathrm{KOH}$ and differentially stained with $0.5 \%$ trypan blue in water (modification of Phillips and Hayman 1970). Percentage mycorrhizal coloniza-

Table 1. Percentage colonization, number of tillers per plant, shoot weight, root weight, and root/shoot ratio, of 3 Nebraska Sandhills warm-season grasses inoculated with Glomus deserticola or Sandhills VAM, and a noninoculated control during 2 greenhouse studies at $P$ levels of 5.4 mg $^{P}$ pot ${ }^{-1}$.

\begin{tabular}{|c|c|c|c|c|c|c|c|c|c|c|}
\hline \multirow[b]{2}{*}{$\begin{array}{l}\text { Mycorrhizal } \\
\text { treatment }\end{array}$} & \multicolumn{5}{|c|}{ First study } & \multicolumn{5}{|c|}{ Second study } \\
\hline & $\begin{array}{l}\text { Colon- } \\
\text { ization }\end{array}$ & Tiller & $\begin{array}{l}\text { Shoot } \\
\text { weight }\end{array}$ & $\begin{array}{c}\text { Root } \\
\text { weight }\end{array}$ & $\begin{array}{l}\text { Root/shoot } \\
\text { ratio }\end{array}$ & $\begin{array}{l}\text { Colon- } \\
\text { ization }\end{array}$ & Tiller & $\begin{array}{l}\text { Shoot } \\
\text { weight }\end{array}$ & $\begin{array}{c}\text { Root } \\
\text { weight }\end{array}$ & $\begin{array}{l}\text { Root/shoot } \\
\text { ratio }\end{array}$ \\
\hline & $(\%)$ & \multicolumn{4}{|c|}{ (No.) g dry matter pot ${ }^{-1}$} & $(\%)$ & \multicolumn{4}{|c|}{ (No.) g dry matter pot ${ }^{-1}$} \\
\hline $\begin{array}{l}\text { Sand Bluestem } \\
\text { Control } \\
\text { Sandhills } \\
\text { G. deserticola }\end{array}$ & $\begin{array}{r}0 \\
44 \\
35\end{array}$ & $\begin{array}{l}1.0 \\
2.2 \\
1.8\end{array}$ & $\begin{array}{l}0.16 \\
1.33 \\
1.79\end{array}$ & $\begin{array}{l}0.18 \\
0.98 \\
1.61\end{array}$ & $\begin{array}{l}1.15 \\
0.75 \\
0.90\end{array}$ & $\begin{array}{r}0 \\
15 \\
43\end{array}$ & $\begin{array}{l}1.0 \\
3.0 \\
2.7\end{array}$ & $\begin{array}{l}0.14 \\
1.72 \\
2.73\end{array}$ & $\begin{array}{l}0.22 \\
1.44 \\
3.24\end{array}$ & $\begin{array}{l}1.46 \\
0.85 \\
1.20\end{array}$ \\
\hline Contrasts $(\mathrm{P}>\mathrm{F})$ & & & & & & & & & & \\
\hline $\begin{array}{l}\text { Control vs Mycorrhizal } \\
\text { G. deserticola } \\
\text { vs Sandhills }\end{array}$ & $\begin{array}{l}0.01 \\
\text { NS }\end{array}$ & $\begin{array}{l}0.01 \\
\text { NS }\end{array}$ & $\begin{array}{l}0.01 \\
0.01\end{array}$ & 0.01 & $\begin{array}{l}0.01 \\
\text { NS }\end{array}$ & $\begin{array}{l}0.01 \\
0.05\end{array}$ & 0.01 & 0.01 & 0.01 & $\begin{array}{l}0.05 \\
\mathrm{NS}\end{array}$ \\
\hline $\begin{array}{l}\text { Switchgrass } \\
\text { Control } \\
\text { Sandhills } \\
\text { G. deserticola }\end{array}$ & $\begin{array}{r}0 \\
52 \\
44\end{array}$ & $\begin{array}{l}1.0 \\
2.9 \\
2.8\end{array}$ & $\begin{array}{l}0.08 \\
1.43 \\
2.58\end{array}$ & $\begin{array}{l}0.06 \\
1.61 \\
1.72\end{array}$ & $\begin{array}{l}0.98 \\
0.44 \\
0.69\end{array}$ & $\begin{array}{r}0 \\
29 \\
27\end{array}$ & $\begin{array}{l}1.1 \\
3.3 \\
3.7\end{array}$ & $\begin{array}{l}0.10 \\
2.57 \\
3.21\end{array}$ & $\begin{array}{l}0.11 \\
2.29 \\
3.46\end{array}$ & $\begin{array}{l}1.26 \\
0.88 \\
1.08\end{array}$ \\
\hline Contrasts $(P>F)$ & & & & & & & & & & \\
\hline $\begin{array}{l}\text { Control vs Mycorrhizal } \\
\text { G. deserticola } \\
\text { vs Sandhills }\end{array}$ & $\begin{array}{l}0.01 \\
\text { NS }\end{array}$ & 0.01 & 0.01 & 0.01 & 0.01 & 0.01 & 0.01 & 0.01 & 0.01 & $\begin{array}{l}\text { NS } \\
\text { NS }\end{array}$ \\
\hline $\begin{array}{l}\text { Prairie Sandreed } \\
\text { Control } \\
\text { Sandhills } \\
\text { G. deserticola }\end{array}$ & $\begin{array}{r}0 \\
35 \\
51\end{array}$ & $\begin{array}{l}1.0 \\
1.2 \\
1.7\end{array}$ & $\begin{array}{l}0.16 \\
0.61 \\
1.29\end{array}$ & $\begin{array}{l}0.15 \\
0.70 \\
1.61\end{array}$ & $\begin{array}{l}1.01 \\
1.20 \\
1.25\end{array}$ & $\begin{array}{r}0 \\
24 \\
27\end{array}$ & $\begin{array}{l}1.1 \\
1.4 \\
2.3\end{array}$ & $\begin{array}{l}0.31 \\
1.52 \\
3.00\end{array}$ & $\begin{array}{l}0.32 \\
1.52 \\
3.41\end{array}$ & $\begin{array}{l}0.89 \\
1.00 \\
1.12\end{array}$ \\
\hline Contrasts $(P>F)$ & & & & & & & & & & \\
\hline $\begin{array}{l}\text { Control vs Mycorrhizal } \\
\text { G. deserticola } \\
\text { vs Sandhills }\end{array}$ & 0.01 & 0.01 & 0.01 & 0.01 & NS & 0.01 & 0.01 & 0.01 & 0.01 & NS \\
\hline
\end{tabular}

NS = Not significant at the 0.05 probability level. 
tion was determined by examining 100 root intercepts of each sample at $100 \mathrm{X}$ magnification using the grid intersection method of Giovanetti and Mosse (1980). The 3 plants in each pot were combined for analysis and each pot was considered an experimental unit.

The first study involved a factorial arrangement of 3 grass species and 3 VAM treatments with 10 replications arranged in a completely randomized design. The second study had the additional factor of $5 \mathrm{P}$ levels and 6 replications. A grass species by VAM treatment interaction was significant for most plant responses studied, so data were analyzed and presented separately for each grass. Significant mycorrhizal and $P$ treatment main effects and interactions were analyzed using preplanned orthogonal contrasts (Steel and Torrie 1980). Contrasts for the mycorrhizal treatments compared the noninoculated control versus VAM inoculated treatments, and compared the 2 different VAM treatments. Plant responses over the $5 \mathrm{P}$ levels were analyzed by regression analysis using orthogonal polynomials for significant linear, quadratic, and cubic responses (Steel and Torrie 1980).

\section{Results and Discussion}

\section{Percentage Colonization}

In the first trial, $G$. deserticola produced significantly greater colonization compared to Sandhills VAM in prairie sandreed, but there were no significant differences in percentage colonization between $G$. deserticola and Sandhills VAM in sand bluestem and switchgrass (Table 1). In the second trial, at $5.4 \mathrm{mg} \mathrm{Pot}^{-1} \mathrm{G}$. deserticola produced greater percentage colonization than Sandhills VAM only for sand bluestem.

The VAM response to $P$ was consistent over all 3 grasses for both VAM treatments. A significant mycorrhizal by $P$ interactions for percentage colonization $(P<0.05)$ was detected as increased $P$ levels produced a quadratic response in percentage to colonization by $G$. deserticola, but had no significant effect on percentage colonization by Sandhills VAM (Fig. 1). Percentage colonization by $G$. deserticola increased from the lowest $P$ level and maximized at $8.9 \mathrm{mg} \mathrm{Pot}^{-1}$, then decreased dramatically at higher $P$ rates. The effect of increased $P$ supply on the colonization rate varies markedly between VAM species (Marschner 1986). At the lowest $P$ level the colonization rate by $G$. deserticola may have been inhibited by insufficient $P$ for optimum growth of the fungus (Bolan et al. 1984), with maximum percentage colonization achieved at a $P$ level that produced $85 \%$ of maximum shoot growth. The inhibitory effect of high P levels on VAM colonization has been documented (Jasper et al. 1979, Hayman 1983), but with Sandhills VAM the generally low level of colonization for all $\mathbf{P}$ levels may account for the lack of an inhibitory effect of high $\mathbf{P}$ levels on percentage colonization.

\section{Tiller Number and Shoot Weight}

At $5.4 \mathrm{mg} \mathrm{P}^{\mathrm{P}}$ pot $^{-1}$, mycorrhizal inoculated plants had significantly greater tillering compared to noninoculated plants for all 3 grasses in both trials (Table 1). The degree to which plant tillering was stimulated varied with each grass-VAM species combination, resulting in a significant grass by VAM treatment interaction in both trials $(P<0.01)$. In the first trial, sand bluestem and switchgrass produced the most tillers when inoculated with Sandhills VAM, but prairie sandreed produced the most tillers with $G$. deserticola. Again, the second trial, sand bluestem produced more tillers when inoculated with Sandhills VAM, but prairie sandreed and switchgrass produced more tillers when inoculated with $G$. deserticola.

Plant tillering was stimulated by $P$ as indicated by a significant quadratic response to increasing $P$ levels (Fig. 2). The tillering response to $P$ was similar for all 3 grasses and VAM treatments.

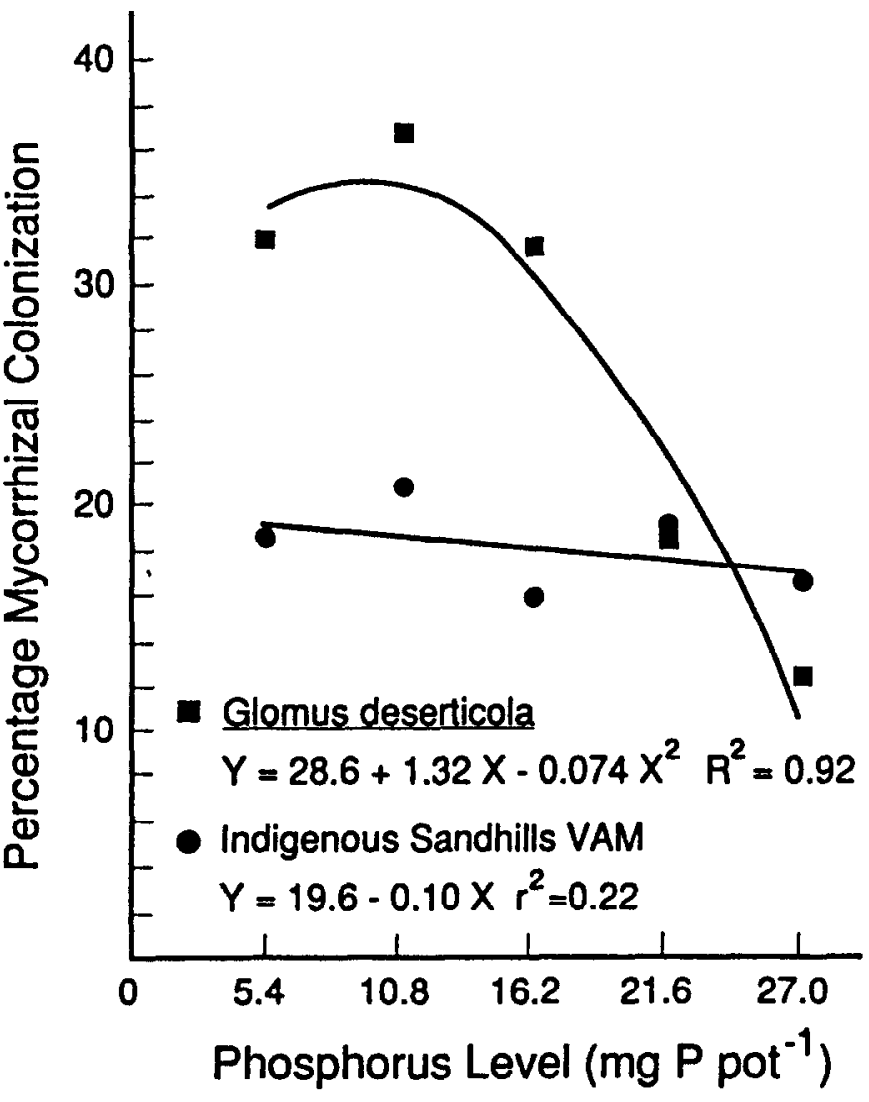

Fig. 1. Percentage colonization by Glomus deserticola and indigenous Sandhills VAM with increasing $P$ levels ( $\mathrm{mg}_{\mathrm{g}} \mathbf{P}$ pot $^{-1}$ ) averaged over Nebraska Sandhills warm-season grasses.

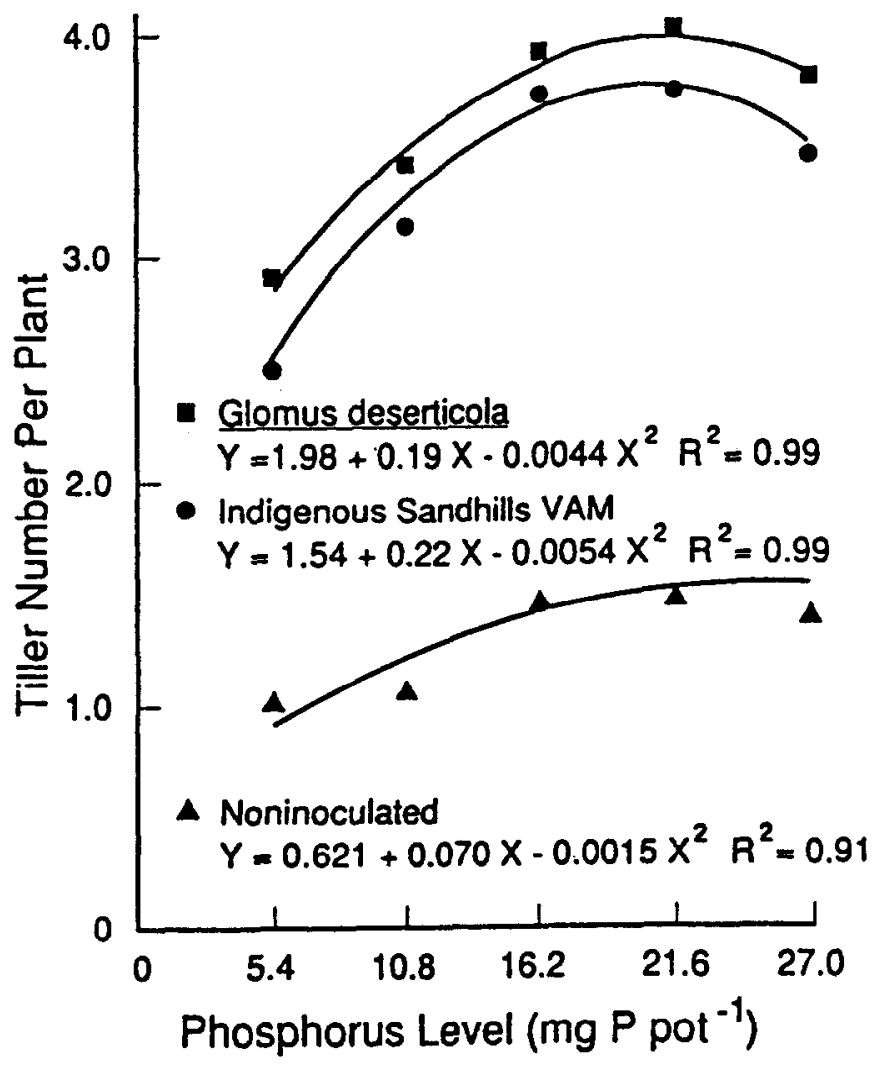

Fic. 2. Tiller numbers per plant with Increasing $P$ levels ( $m g$ pot ${ }^{-1}$ ) averaged over 3 Nebraska Sandhilk warm-season grasses inoculated with Glomus deserticols, indigenous Sandhills VAM and a noninoculated control 
Plants inoculated with VAM produced 2 to 3 times more tillers than noninoculated plants. Based upon the fitted regression equations, maximum tiller numbers were achieved at about $21.6 \mathrm{mg} \mathrm{P}$ pot $^{-1}$, with a decrease in tiller numbers at higher P levels (Fig. 2).

At the $5.4 \mathrm{mg} \mathrm{P} \mathrm{pot}^{-1}$ level, shoot weight of VAM-inoculated plants was significantly greater than shoot weight of noninoculated plants $(P<0.01)$, and $G$. deserticola-inoculated plants produced significantly greater shoot weights than Sandhills V $\Lambda \mathrm{M}$-inoculated plants in both trials (Table 1). Different plant responses for tillering and shoot weights were confirmed by the low correlation between these 2 parameters $(r=0.35)$. Shoot weights of VAMinoculated plants were not correlated with percentage colonization in either trial. Hayman (1983) reported there is no definite correlation between the amount of VAM colonization of the root and the enhancement of plant growth. Thus, the most infective fungi do not necessarily elicit the most positive responses.

A highly significant grass species by VAM treatment interaction occurred with shoot weight $(P<0.01)$ (Table 1). The interaction was caused by the magnitude of the response to the different VAM treatments. In both trials, $G$. deserticola increased shoot yields of all grasses over that of grasses inoculated with Sandhills VAM. The yield increase caused by $G$. deserticola was much greater for prairie sandreed than for sand bluestem and switchgrass.

A significant VAM treatment by $P$ response for shoot weight was characterized by significantly different quadratic curves for noninoculated and VAM-inoculated plants (Fig. 3). The VAM response to $\mathbf{P}$ was similar for the 3 grasses. Shoot weights of the noninoculated grasses increased with increasing levels of $P$, with

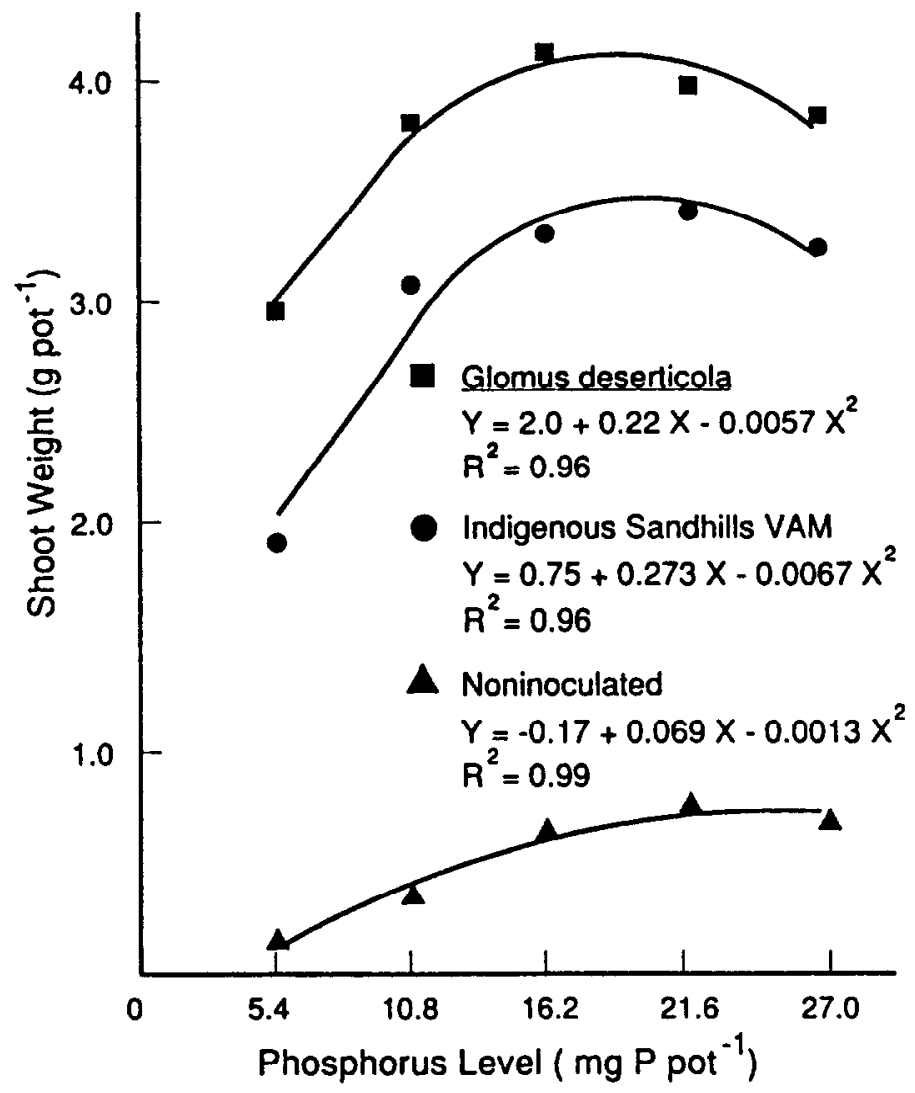

Fig. 3. Shoot weight $\left(\mathrm{g} \mathrm{pot}^{-1}\right)$ with increasing $P$ levels $\left(\mathrm{mg} \mathrm{P} \mathrm{pot}{ }^{-1}\right)$ averaged over 3 Nebraska Sandhills warm-season grasses inoculated with Glomus deserticola, indigenous Sandhills VAM and a noninoculated control maximum shoot weight at the highest $P$ level. However, even at the highest $P$ levels, shoot weight of noninoculated plants was less than half that of VAM-inoculated plants at the lowest $P$ rate. Mycorrhizal-inoculated plants had large increases in shoot weight from 5.4 to $10.8 \mathrm{mg} \mathrm{P} \mathrm{pot}^{-1}$, followed by gradual increases and then a decline as $P$ levels increased to $27 \mathrm{mg} \mathrm{P}$ pot $^{-1}$. Based upon fitted regression equations, shoot weights of $G$. deserticola-inoculated plants were greatest at $19.3 \mathrm{mg} \mathrm{P}^{\mathrm{P}}$ pot $^{-1}$ with a decline in shoot weights at higher P levels; and shoot weights of Sandhills VAMinoculated plants were greatest at $20.2 \mathrm{mg} \mathrm{P}^{-1}$ with a decline in shoot weights at higher $P$ levels.

\section{Root Weight and Root/Shoot Ratio}

Root weights of mycorrhizal-inoculated plants were greater than root weights of noninoculated plants (Table 1), and $G$. deserticola-inoculated plants had greater root weights than plants inoculated with Sandhills VAM for all 3 grasses in both trials. Root yields of prairie sandreed plants inoculated with $G$. deserticola were more than double those of plants inoculated with Sandhills VAM. Increasing P levels caused linear increases in root weight, with the response being similar over all grasses and mycorrhizal treatments.

Response of root/shoot ratio to the VAM treatments varied by species (Table 1). Root/shoot ratios of VAM-treated sand blue blucstem were less than ratios for noninoculated plants in both trials. Switchgrass root/shoot ratios were less when inoculated with VAM in trial 1 . While not significant, a similar response occurred in trial 2. In prairie sandreed, the VAM treatments increased the root and shoot weights by a similar magnitude so the root/shoot ratios were not different from those of noninoculated plants. Other researchers have reported lower root/shoot ratios in mycorrhizal compared to nonmycorrhizal plants (Mosse and Hayman 1971, Hayman and Mosse 1972).

A significant quadratic response in root/shoot ratios occurred over $P$ levels. The response was similar for all 3 grasses and mycorrhizal treatments and resulted from a sharp decline in root/ shoot ratios between $5.4-16.2 \mathrm{mg} P$ pot ${ }^{1}$, with no change in root/shoot ratios at higher $P$ levels (data not shown).

\section{Phosphorus Concentration, Recovery, and Efficiency}

Mycorrhizal-inoculated plants had significantly greater shoot $P$ concentrations over noninoculated plants in both trials $(P<0.01$, Table 2). In general, the Sandhills VAM increased shoot $P$ concentration more than $G$. deserticola. In the first trial, $P$ concentration in the grass shoots followed a similar pattern as percentage colonization in which sand bluestem and switchgrass had the greatest shoot $P$ concentration when inoculated with Sandhills VAM. Although prairie sandreed had the greatest shoot $P$ concentration when inoculated with $G$. deserticola, it was not significantly greater than that for Sandhills VAM. In the second trial, percentage colonization and shoot $P$ concentration followed an opposite pattern in which $G$. deserticola produced the greatest percentage colonization for all 3 grasses, but Sandhills VAM-inoculated plants produced the greatest shoot $\mathbf{P}$ concentration in sand bluestem and prairie sandreed.

A significant grass species by VAM treatment by $P$ level interaction was observed for shoot $P$ concentration ( $P<0.01$, Fig. 4 ). Shoot $P$ concentrations of VAM-inoculated plants were similar for all 3 grasses over all $P$ levels. Mycorrhizal-inoculated plants increased in shoot $P$ concentration with increasing $P$ rates from 5.4-21.6 mg $P$ pot $^{-1}$, with maximum shoot $P$ concentration at a $P$ level of $23 \mathrm{mg} \mathrm{P}^{-1}$, based upon fitted regression equations. However, noninoculated sand bluestem had significantly lower shoot $P$ concentrations than noninoculated switchgrass and prairie sandreed, and responded differently to increasing $P$ levels, which suggested that sand bluestem may have the lowest physiological $\mathrm{P}$ requirement. Sand bluestem showed a linear increase in 
Table 2. Phosphorus concentration, percent recovery and phosphorus efficiency by shoots of 3 Nebraska Sandhills warm-season grasses inoculated with Glomus deserticola or Sandhills VAM or non-inoculated control for 2 greenhouse studies at P levels of $5.4 \mathrm{mg} \mathrm{pot}^{-1}$.

\begin{tabular}{|c|c|c|c|c|c|c|}
\hline \multirow[b]{2}{*}{ Mycorrhizal treatment } & \multicolumn{3}{|c|}{ First study } & \multicolumn{3}{|c|}{ Second study } \\
\hline & Concentration & Recovery & Efficiency & Concentration & Recovery & Efficiency \\
\hline & $\begin{array}{c}\text { (mg P g } \\
\text { matter }\end{array}$ & $(\%)$ & $\begin{array}{l}\text { (g dry matter } \\
\mathrm{mg} \mathrm{P}^{-1}\end{array}$ & $\begin{array}{c}\text { (mg P g } \\
\text { dry matter) }\end{array}$ & $(\%)$ & $\begin{array}{l}\text { (g dry matter } \\
\text { mg P }^{-1} \text { ) }\end{array}$ \\
\hline $\begin{array}{l}\text { Sand Bluestem } \\
\text { Control } \\
\text { Sandhills } \\
\text { G. deserticola }\end{array}$ & $\begin{array}{r}40 \\
100 \\
75\end{array}$ & $\begin{array}{r}1.3 \\
26.2 \\
23.7\end{array}$ & $\begin{array}{l}2.54 \\
1.01 \\
1.34\end{array}$ & $\begin{array}{l}40 \\
84 \\
75\end{array}$ & $\begin{array}{r}1.2 \\
26.6 \\
37.9\end{array}$ & $\begin{array}{l}2.50 \\
1.20 \\
1.34\end{array}$ \\
\hline \multicolumn{7}{|l|}{ Contrasts $(P>F)$} \\
\hline $\begin{array}{l}\text { Control vs Mycorrhizal } \\
\text { G. deserticola vs Sandhills }\end{array}$ & $\begin{array}{l}0.01 \\
0.01\end{array}$ & $\begin{array}{l}0.01 \\
\text { NS }\end{array}$ & $\begin{array}{l}0.01 \\
0.05\end{array}$ & $\begin{array}{l}0.01 \\
0.05\end{array}$ & $\begin{array}{l}0.01 \\
0.01\end{array}$ & $\begin{array}{l}0.01 \\
0.05\end{array}$ \\
\hline $\begin{array}{l}\text { Switchgrass } \\
\text { Control } \\
\text { Sandhills } \\
\text { G. deserticola }\end{array}$ & $\begin{array}{r}52 \\
102 \\
70\end{array}$ & $\begin{array}{r}0.6 \\
25.8 \\
32.4\end{array}$ & $\begin{array}{l}2.04 \\
0.99 \\
1.46\end{array}$ & $\begin{array}{l}48 \\
76 \\
72\end{array}$ & $\begin{array}{r}0.9 \\
36.0 \\
42.8\end{array}$ & $\begin{array}{l}2.14 \\
1.34 \\
1.39\end{array}$ \\
\hline \multicolumn{7}{|l|}{ Contrasts $(\mathrm{P}>\mathrm{F})$} \\
\hline $\begin{array}{l}\text { Control vs Mycorrhizal } \\
G \text {. deserticola vs Sandhills }\end{array}$ & $\begin{array}{l}0.01 \\
0.01\end{array}$ & $\begin{array}{l}0.01 \\
\text { NS }\end{array}$ & $\begin{array}{l}0.01 \\
0.05\end{array}$ & $\begin{array}{l}0.01 \\
\text { NS }\end{array}$ & $\begin{array}{l}0.01 \\
\text { NS }\end{array}$ & $\begin{array}{l}0.01 \\
\text { NS }\end{array}$ \\
\hline $\begin{array}{l}\text { Prairie Sandreed } \\
\text { Control } \\
\text { Sandhills } \\
\text { G. deserticola }\end{array}$ & $\begin{array}{r}66 \\
98 \\
126\end{array}$ & $\begin{array}{c}17.7 \\
12.7 \\
30.5\end{array}$ & $\begin{array}{l}1.79 \\
1.04 \\
0.81\end{array}$ & $\begin{array}{l}53 \\
78 \\
64\end{array}$ & $\begin{array}{r}2.5 \\
21.8 \\
35.6\end{array}$ & $\begin{array}{l}1.99 \\
1.30 \\
1.57\end{array}$ \\
\hline \multicolumn{7}{|l|}{ Contrasts $(P>F)$} \\
\hline $\begin{array}{l}\text { Control vs Mycorrhizal } \\
\text { G. deserticola vs Sandhills }\end{array}$ & $\begin{array}{l}0.01 \\
\text { NS }\end{array}$ & $\begin{array}{l}0.01 \\
0.01\end{array}$ & $\begin{array}{l}0.01 \\
\text { NS }\end{array}$ & $\begin{array}{l}0.01 \\
0.01\end{array}$ & $\begin{array}{l}0.01 \\
0.01\end{array}$ & $\begin{array}{l}0.01 \\
\text { NS }\end{array}$ \\
\hline
\end{tabular}

NS $=$ Not significant at the 0.05 probability level.

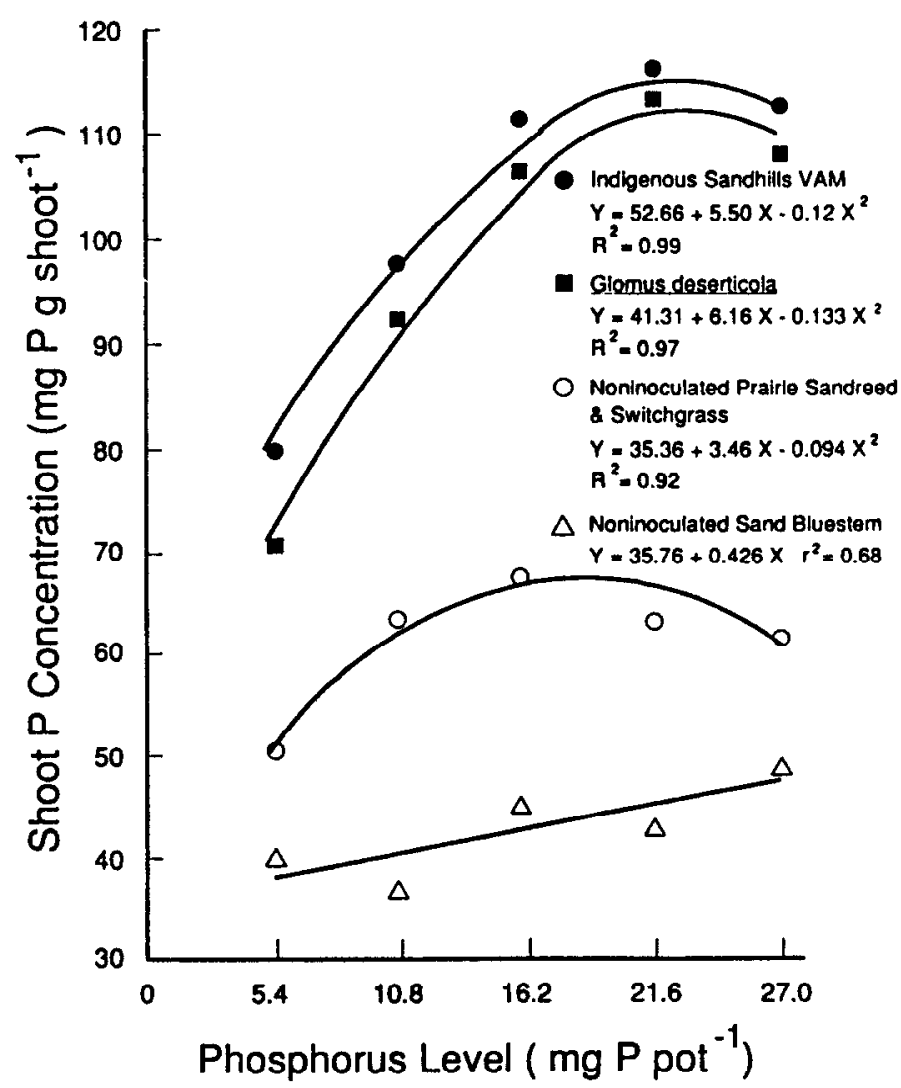

Fig. 4. Shoot $P$ concentration ( $\mathrm{mg}^{\mathrm{P}} \mathrm{g}$ shoot ${ }^{-1}$ ) with increasing $\mathrm{P}$ levels (mg $P$ pot ${ }^{-1}$ ) averaged over 3 Nebraska Sandhills warm-season grasses inoculated with Glomus deserticola or indigenous Sandhills VAM, and for noninoculated sand bluestem and an average of noninoculated prairie sandreed and switchgrass. shoot $P$ concentration with increasing $P$ levels, but shoot $P$ concentration of sand bluetem at the highest $P$ level was similar to shoot $P$ concentration of switchgrass and prairie sandreed at the lowest $P$ level. Noninoculated switchgrass and prairie sandreed had similar quadratic responses to increasing $\mathbf{P}$ levels. Maximum shoot $\mathbf{P}$ concentration occurred at a $P$ level of $21.6 \mathrm{mg} \mathrm{P}^{-1}$. A 5-fold increase in the $\mathbf{P}$ fertilization rate failed to raise the shoot $\mathbf{P}$ concentration of noninoculated control plants to the same level achieved with VAM at the lowest $P$ rate.

Mycorrhizal-inoculated plants recovered a much greater percentage $\mathrm{P}$ compared to noninoculated plants in both trials (Table 2). The $G$. deserticola-inoculated plants generally were more efficient in recovering applied $P$ than Sandhills VAM-inoculated plants when averaged over all 3 grasses, but the total percentage $P$ recovered depended on the grass species involved, resulting in significant grass species by VAM treatment interactions for both trials $(P<0.01)$. In the first trial $G$. deserticola-inoculated prairie sandreed plants recovered more $P$ than Sandhills VAM-inoculated plants but differences in $P$ recovery were not significantly different from the 2 VAM inocula for switchgrass and sand bluestem. A similar pattern was observed in the second trial, with mycorrhizalinoculated plants recovering significantly more $P$ than noninoculated plants, and $G$. deserticola-inoculated plants recovering more $P$ than Sandhills VAM-inoculated plants for sand bluestem and prairie sandreed.

Increasing $P$ levels resulted in a significant linear decrease in percentage $P$ recovered by VAM-inoculated plants, but had no effect on percentage $P$ recovered by noninoculated plants (Fig. 5). The response was similar for all 3 grasses. The rate of decline in percentage $P$ recovered with increasing $P$ levels was significantly different for the 2 VAM treatments in which percentage $P$ recovered by $G$. deserticola-inoculated plants declined more rapidly than percentage $P$ recovered by Sandhills VAM-inoculated plants.

Shoot $P$ concentration and $P$ efficiency $(P E)$ varied inversely. The grass species-VAM treatment combinations with the highest shoot $\mathrm{P}$ concentrations had the lowest PE. Noninoculated plants 


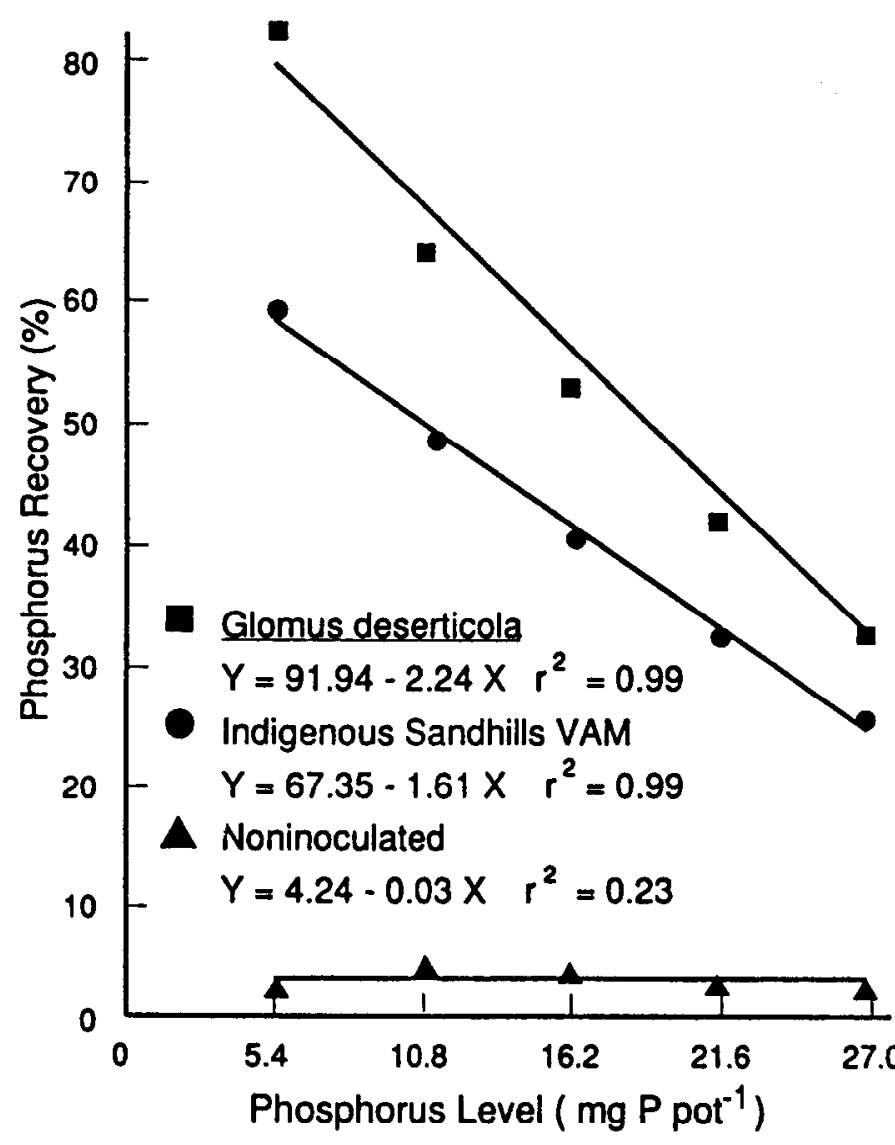

Fig. 5. Percentage $P$ recovered with increasing $P$ levels ( $\mathrm{mg} P$ pot $^{-1}$ ) averaged over 3 Nebraska Sandhills warm-season grasses inoculated with Glomus deserticola, indigenous Sandhills VAM and a noninoculated control.

had significantly greater PE than VAM inoculated plants, with sand bluestem being the most efficient of all 3 grasses (Table 2). In general, plants inoculated with $G$. deserticola had greater $P E$ than plants inoculated with Sandhills VAM, but differences were significant only for sand bluestem in both trials and switchgrass in the first trial. In the second trial, differences in PE between $G$. deserticola and Sandhills VAM-inoculated plants were very small.

Increased $P$ level resulted in a significant decrease in PE for all grasses and VAM treatments (Fig. 6). A significant VAM treatment by $P$ level by grass species interaction occurred, resulting from a much greater $P E$ in noninoculated sand bluestem than noninoculated prairie sandreed or switchgrass. Noninoculated sand bluestem showed a linear decline in PE with increasing $P$ levels, but noninoculated prairie sandreed and switchgrass produced similar quadratic responses with a dramatic decline in $P E$ up to $19 \mathrm{mg} \mathrm{P}$ pot $^{-1}$, then a small increase in PE at higher $\mathrm{P}$ levels. Elliott and Lauchli (1985) and Marschner (1986) reported that plants varied considerably among species and genotypes within species in PE, and possess both physiological and morphological characteristics that affect PE. Noninoculated sand bluestem had a greater PE than noninoculated prairie sandreed and switchgrass, or VAM-inoculated plants. Response of VAM-inoculated plants was similar for all 3 grasses over all P levels. Phosphorus efficiency of VAM-inoculated plants declined with increased P levels up to $16.2 \mathrm{mg} \mathrm{P}$ pot $^{-1}$, with no significant change in $P E$ at higher $P$ levels.

Results from this study suggest that 3 of the major climax grasses

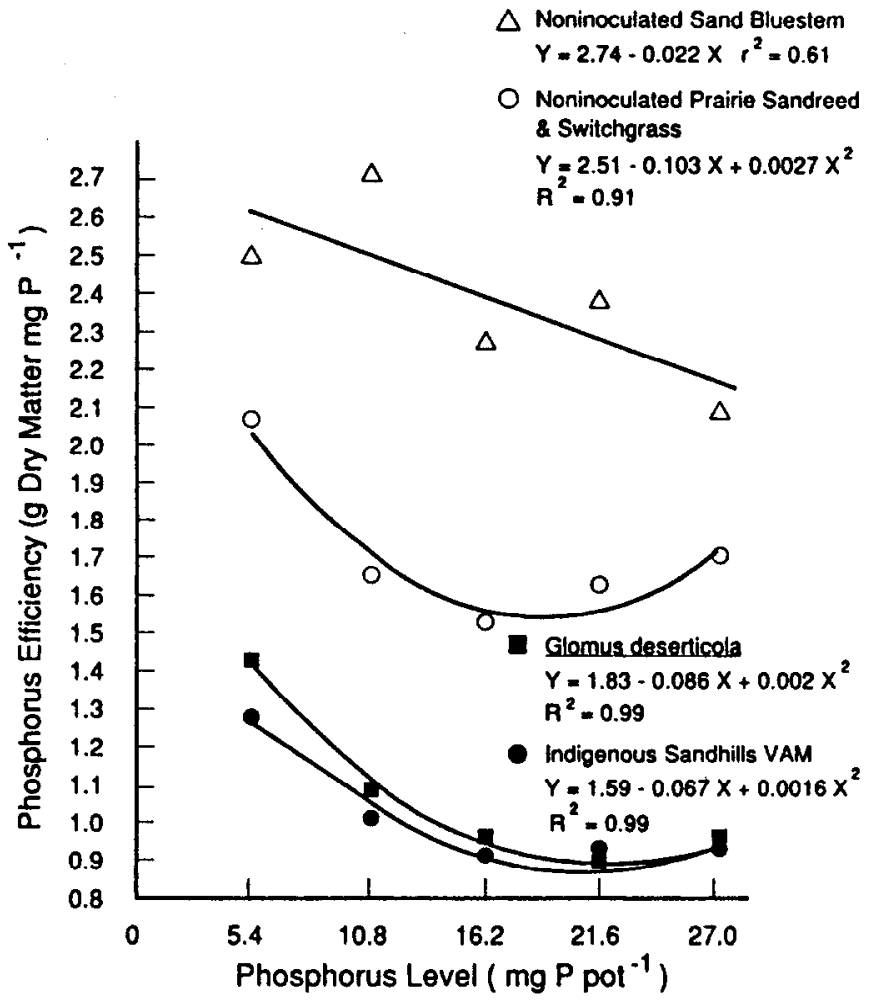

Fig. 6. Phosphorus efficiency (PE) (mg dry matter $\mathrm{mg}^{-1}$ accumulated) with increasing $P$ levels $\left(\mathrm{mg} \mathrm{P}\right.$ pot $\left.^{-1}\right)$ averaged over 3 Nebraska Sandhills warm-season grasses inoculated with Glomus deserticola, indigenous Sandhills VAM, noninoculated sand bluestem and an average of noninoculated prairie sandreed and switchgrass.

of the Sandhills are highly mycorrhizal dependent and the low density or absence of mycorrhizae in the eroding soils of blowouts and abandoned center pivots may inhibit the revegetation of these sites by these warm-season grasses. A 5-fold increase in $\mathrm{P}$ fertilizer did not stimulate as vigorous plant responses as inoculation with VAM.

At present, the technology for obtaining sufficient quantities of VAM inoculum, and for direct, widespread and economical reintroduction of mycorrhizae into rangeland and soils has not been developed. Therefore, alternative methods need to be developed for the reintroduction of VAM and revegetation of actively eroding Sandhills soils. One possibility could be to speed-up natural succession by growing a facultatively mycorrhizal annual cover crop on these sites that could help stabilize the eroding soil and serve as a host for reestablishment of mycorrhizal fungi and as a bridge for passage of mycorrhizae to perennial Sandhills warmseason grasses that could be seeded later.

\section{Literature Cited}

Bethlenfalvay, G.F., S. Dakessian, and R.S. Pacovsky. 1984. Mycorrhizae in a southern California Desert: Ecological implications. Can. J. Bot. 62:519-524.

Bolan, N.S., A.D. Robson, and N.J. Barrow. 1984. Increasing phosphorus supply can increase the colonization of plant roots by vesiculararbuscular mycorrhizal fungi. Soil Biol. Biochem. 16:419-420.

Burzlaff, D.F. 1962. A soil and vegetation inventory and analysis of three Nebraska Sandhills range sites. Univ. Nebr. Agr. Exp. Sta. Bull. 206. Univ. Nebraska, Lincoln.

Elliott, G.C., and A. Lauchli. 1985. Phosphorus efficiency and phosphateiron interaction in maize. Agron. J. 77:399-403. 
Giovannetti, M., and B. Mosse. 1980. An evaluation of techniques for measuring vesicular-arbuscular mycorrhizal colonization in roots. New Phytol. 84:489-500.

Hayman, D.S. 1983. The physiology of vesicular-arbuscular endomycorrhizal symbiosis. Can. J. Bot. 61:944-963.

Hayman, D.S., and B. Mosse. 1972. Plant growth responses to vesiculararbuscular mycorrhiza III. Increased uptake of labile P from soil. New Phytol. 71:41-47.

Hetrick, B.A.D., D.G. Kitt, and G.T. Wilson. 1988. Mycorrhizal dependence and growth habit of warm-season and cool-season tallgrass prairie plants. Can. J. Bot. 66:1376-1380.

Hetrick, B.A.D., G.W.T Wilson, and C.E. Owensby. 1989. Influence of mycorrhizal fungi and fertilization on big bluestem seedling biomass. $J$. Range Manage. 42:213-216.

Hewitt, E.J. 1966. Sand and water culture methods used in the study of plant nutrition. Tech. Commun. 22(2nd Ed.). Commonwealth Bureau of Horticulture and Plantation Crops. East Malling, Maidstone, Kent. Commonwealth Agr. Bur., Farnham Agr. Bur., Farnham Royal.

Jasper, D.A., A.D. Robson, and L.K. Abbott. 1979. Phosphorus and the formation of vesicular-arbuscular mycorrhizae. Soil Biol. Biochem. 11:501-505.

King, M.A., S.S. Waller, L.E. Moser, and J.L. Stubbendieck. 1989. Seedbed effects on grass establishment on abandoned Nebraska Sandhills cropland. J. Range Manage. 42:183-187.

Kocher, E., and J. Stubbendieck. 1986. Broadcasting grass seed to revegetate sandy soils. J. Range Manage. 39:555-557.

Linderman, R.G., and J.W. Hendrix. 1982. Evaluation of plant response to colonization by vesicular-arbuscular mycorrhizal fungi, A. Host variables, p. 69-76. In: N.C. Schenck (ed), Methods and principles of mycorrhizal research. The American Phytopathological Society, St. Paul, Minn.
Marschner, H. 1986. Mineral nutrition in higher plants. Academic Press Inc., London.

Mosse, B., and D.S. Hayman. 1971. Plant growth responses to vesiculararbuscular mycorrhiza. II. In unsterilized field soils. New Phytol. 70:29-34.

Phillips, J.M., and D.S. Hayman. 1970. Improved procedures for clearing roots and staining parasitic and vesicular-arbuscular mycorrhizal fungi for rapid assessment of colonization. Trans. Br. Mycol. Soc. 55:158-161.

Reece, P.E., D.H. Yocom, and M.G. Boosalis. 1987. Role of mycorrhizae in revegetation of eroded Sandhills soils. p. 164. In: D.M. Sylvia, L.L. Hung, and J.H. Graham (eds.). Mycorrhizae in the next decade. Institute Food and Agr. Sci., Univ. Florida, Gainesville.

Reeves, F.B., B. Wagner, T. Moorman, and J. Kiel. 1979. The role of endomycorrhizae in revegetation practices in the semi-arid west. I. A comparison of incidence of mycorrhizae in severely disturbed vs. natural environments. Amer. J. Bot. 66:6-13.

Roder, W. 1985. Factors influencing grass seeding success on a sandy soil. M.S. Thesis, Univ., Nebraska, Lincoln.

Seevers, P.M., D.T. Lewis, and J.S. Drew. 1975. Use of ERTS-1 imagery to interpret the wind erosion hazard in Nebraska's Sandhills. I. Soil and Water Conserv. 30:181-183.

Steel, R.G.D., and J.H. Torrie. 1980. Principles and procedures of statistics. McGraw-Hill Co. N.Y.

Trappe, J.M. 1981. Mycorrhizae and productivity of arid and semiarid rangelands, p. 581-599. In: J.T. Manassah and E.J. Briskey (eds.), Advances in food producing systems for arid and semiarid lands. Academic Press, N.Y. 